\title{
Photodistributed chickenpox in a 3-year-old boy
}

\author{
Adrien Mareschal MD, Dominique Blanc MD, François Aubin MD PhD
}

Cite as: CMAJ 2021 March 22;193:E425. doi: 10.1503/cmaj.201771

A 3-year-old boy was referred to the dermatology department with a 1-day history of temperature of $38.5^{\circ} \mathrm{C}$, myalgia and bilateral itchy, vesicular eruptions on both of his forearms and his neck (Figure 1 and Appendix 1, available at www.cmaj. ca/lookup/doi/10.1503/cmaj.201771/tab-related-content). Some scattered vesicles were also present on non-photo-exposed areas. He had no medical history, had not received the varicella vaccination, and his older brother had developed chickenpox 2 weeks earlier. Two days before the eruption, the child had spent a sunny afternoon outdoors dressed in a T-shirt. Culture from a vesicle confirmed varicella-zoster virus infection. We prescribed acetaminophen and aqueous chlorhexidine for symptomatic relief, and the patient's lesions resolved within 2 weeks.

Without vaccination, up to $96 \%$ of children develop chickenpox, most within the first 5 years of life. ${ }^{1}$ Infection is characterized by the simultaneous presence of vesicular, erosive and crusty lesions, sometimes umbilicated, which usually occur in crops. ${ }^{2}$ Although considered benign, with most children having a mild course, the most common complication is superimposed bacterial infection (impetiginization) with Staphylococcus aureus and Streptococcus pyogenes, requiring antibacterial treatment. ${ }^{3}$

Ultraviolet (UV) rays are known to exacerbate cutaneous herpes infection, but photodistributed chickenpox is an atypical presentation. ${ }^{3}$ In photodistributed disease, skin lesions are slightly larger than in typical chickenpox (usually 1-2 $\mathrm{mm}$ ), the rash is monomorphous and the lesions are in a similar stage of evolution. ${ }^{4}$ The pathogenesis remains unclear, although it is proposed that UV rays induce local vasodilatation and increase capillary permeability, particularly during viremia. ${ }^{4}$ UV radiation, furthermore, induces local immunosuppression by secretion of anti-inflammatory cytokines, including interleukin 10 , which may lead to photodistribution of lesions. ${ }^{5}$

\section{References}

1. European Centre for Disease Prevention and Control (ECDC). ECDC guidance: varicella vaccination in the European Union. Stockholm: ECDC; 2015. Available: https://ecdc.europa.eu/sites/portal/files/media/en/publications/Publications/ Varicella-Guidance-2015.pdf (accessed 2020 Sept. 20).

2. Sakiyama M, Maeshima H, Higashino $\mathrm{T}$, et al. Photolocalized varicella in an adult. Br J Dermatol 2014;170:1195-6.

3. Rodriguez-Santana Y, Sanchez-Almeida E, Garcia-Vera C, et al. PAPenRED. Epidemiological and clinical characteristics and the approach to infant chickenpox in primary care. Eur J Pediatr 2019;178:641-8.

4. Osborne GE, Hawk JL. Photodistributed chickenpox mimicking polymorphic light eruption. Br J Dermatol 2000;142:584-5.

5. Aubin F. Mechanisms involved in ultraviolet light-induced immunosuppression. Eur J Dermatol 2003;13:515-23.

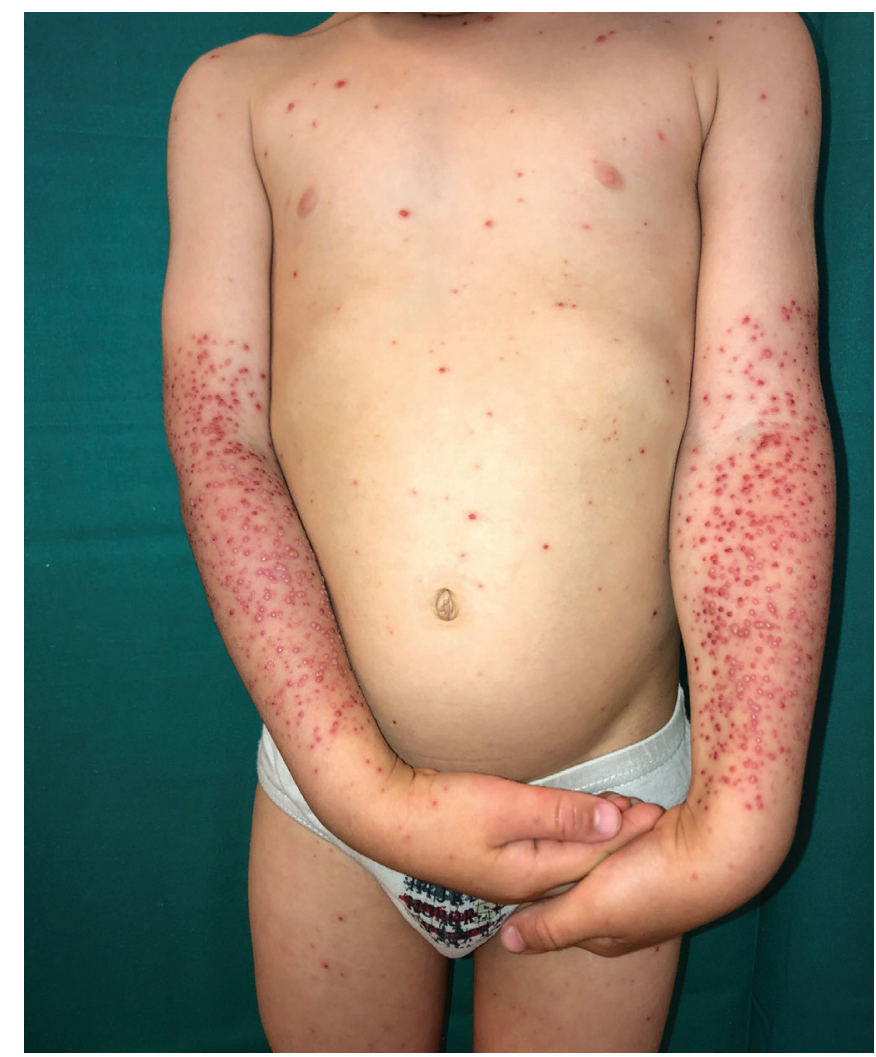

Figure 1: Umbilicated vesicles present in a 3-year-old boy. The vesicles were $2-3 \mathrm{~mm}$ in size and associated with erosions and crusts, bilaterally on the forearms.

Competing interests: None declared.

This article has been peer reviewed.

The authors have obtained consent from the patient's family.

Affiliations: Department of Dermatology, Centre hospitalier régional universitaire (CHRU) de Besançon, Besançon, France

Content licence: This is an Open Access article distributed in accordance with the terms of the Creative Commons Attribution (CC BY-NCND 4.0) licence, which permits use, distribution and reproduction in any medium, provided that the original publication is properly cited, the use is noncommercial (i.e., research or educational use), and no modifications or adaptations are made. See: https://creativecommons.org/ licenses/by-nc-nd/4.0/

Correspondence to: Adrien Mareschal, mareschal.adrien@gmail.com 